\title{
Mortality and hospital admission rates for unintentional nonfire-related carbon monoxide poisoning across Canada: a trend analysis
}

\author{
Eric Lavigne PhD, Scott Weichenthal PhD, Joan Wong MSc, Marc Smith-Doiron BSc, \\ Rose Dugandzic MSc, Tom Kosatsky MD MPH
}

\section{Abstract}

Background: The epidemiology of mortality and morbidity from carbon monoxide poisoning in Canada has received little attention. Our objective was to evaluate trends in mortality and hospital admission rates for unintentional nonfire-related carbon monoxide poisoning across Canada.

Methods: Age- and sex-standardized mortality (1981-2009) and hospital admission (1995-2010) rates by age group, sex and site of carbon monoxide exposure were calculated for each province and for all of Canada. We quantified the long-term trends by calculating the average annual percent change. Multivariable Poisson regression was used to estimate incidence rate ratios (IRRs) of carbon monoxide poisoning across age groups, sex and month of occurrence.

Results: In Canada, there were 1808 unintentional nonfire-related carbon monoxide poisoning deaths between 1981 and 2009 and 1984 admissions to hospital between 1995 and 2010. Average annual decreases of $3.46 \%$ (95\% confidence interval [Cl] $-4.59 \%$ to $-2.31 \%)$ and $5.83 \%(95 \% \mathrm{Cl}-7.79 \%$ to $-3.83 \%)$ were observed for mortality and hospital admission rates, respectively. Mortality (IRR 5.31 , 95\% Cl 4.57 to 6.17) and hospital admission (IRR 2.77, 95\% Cl 2.51 to 3.03) rates were elevated in males compared with females. Decreased trends in the rates were observed for all sites of carbon monoxide exposure, but the magnitude of this decrease was lowest in residential environments. Deaths and admissions to hospital were most frequent from September to April, with peaks in December and January.

Interpretation: Mortality and hospital admission rates for unintentional nonfire-related carbon monoxide poisoning in Canada have declined steadily. Continued efforts should focus on reducing carbon monoxide poisoning during the cooler months and in residential environments.

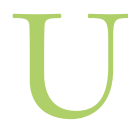
nintentional nonfire-related carbon monoxide poisoning is a leading cause of accidental poisoning in the United States. ${ }^{1,2}$ Exposure to carbon monoxide occurs mostly in indoor home environments through malfunctioning home-heating systems, the operation of gasoline-powered equipment in enclosed or semienclosed areas, and improperly vented gas appliances. ${ }^{3,4}$ Inhalation of carbon monoxide can result in reduced oxygen transport by the blood, a condition that starves the cells and organs in the body. The adverse effects associated with carbon monoxide poisoning vary depending on the level and duration of exposure, and range from minor flulike symptoms and shortness of breath, to confusion, unconsciousness, coma and death. ${ }^{5}$

Since 1968, studies have reported a decrease in mortality and hospital admission rates for this type of carbon monoxide poisoning in the US ${ }^{6-8}$ and in the United Kingdom, ${ }^{9}$ whereas increasing or stable mortality for carbon monoxide poisoning has been reported in other European countries. ${ }^{10}$ There are no reports available on changes in these rates in
Canada. Few studies have provided magnitude estimates of the changes over time in mortality and hospital admissions for carbon monoxide poisoning, and few investigations have evaluated long-term trends in rates as a function of the site of the carbon monoxide exposure. ${ }^{8,9,11}$ There is lack of demographic data in Canada regarding carbon monoxide poisoning.

The aim of this study was to evaluate trends in mortality and hospital admission rates for unintentional nonfire-related carbon monoxide poisoning across Canada, including analyses by province, age, sex, and month and site of occurrence.

Competing interests: None declared.

This article has been peer reviewed.

Correspondence to: Eric Lavigne, eric.lavigne@ @c-sc.gc.ca

CMAJ Open 2015. DOI:10.9778/cmajo.20140122 


\section{Methods}

\section{Data sources}

\section{Mortality data}

We accessed the Vital Statistics Death Database (Statistics Canada) to obtain national data on deaths related to unintentional nonfire-related carbon monoxide poisoning from Jan. 1, 1981, to Dec. 31, 2009. ${ }^{12}$ Diagnosis codes (International Classification of Diseases, 9th Revision codes [ICD-9]; International Statistical Classification of Diseases and Related Health Problems, 10th revision codes [ICD-10]) were used as the basis for extracting the data for unintentional nonfire-related carbon monoxide poisoning deaths from the database. We excluded intentional (i.e., suicide, assault) and fire-related carbon monoxide poisoning from our analysis because the public health prevention strategies for these conditions differ from unintentional nonfire-related carbon monoxide exposures. ${ }^{6} \mathrm{We}$ extracted data for deaths where the primary or secondary cause of death was associated with accidental nonfire-related carbon monoxide poisoning using the following codes: ICD-10 codes X47 or ICD-9 codes E867, E868.0, E868.1, E868.2, E868.3, E868.8 or E868.9. ${ }^{13}$ Extracted data also had to provide a supplementary code to characterize death associated with carbon monoxide poisoning using ICD-10 code T58 or ICD-9 code 986 related to the toxic effect of carbon monoxide. ${ }^{10}$ Case definition for unintentional nonfire-related carbon monoxide poisoning was based on definitions used by the Centers for Disease Control and Prevention for carbon monoxide-related mortality, emergency department visits and hospital admission surveillance. ${ }^{2,11}$ Information on sex, age at death, province in which death occurred and site where the carbon monoxide poisoning occurred were also extracted. The latter was categorized as the following: home/residential, occupational, recreational/sports facility, public area and other/unknown. ${ }^{6}$

\section{Hospital admission data}

Data for admissions to hospital related to carbon monoxide poisoning for the period January 1995 to December 2010 were extracted from the Hospital Morbidity Database (Canadian Institute for Health Information). ${ }^{14}$ Data for admissions to hospital were extracted if ICD-10 code T58 or ICD-9 code 986 was listed in any diagnosis (e.g., most responsible diagnosis, secondary, tertiary, etc.) field. ${ }^{6}$ We used the same ICD-9 and ICD-10 codes mentioned previously to identify cases of accidental nonfire-related carbon monoxide poisoning. Data for sex, age at admission to hospital, province of occurrence and site of carbon monoxide exposure were extracted from the Hospital Morbidity Database. The latter was recorded using ICD codes in secondary diagnosis fields and was categorized as described previously for the mortality data. Using an encrypted health card number for each patient, we deleted duplicate entries, indicating the transfer of patients between hospitals.

\section{Statistical analysis}

We calculated age- and sex-standardized rates of death and admission to hospital per million population for each year of the corresponding time periods. The number of deaths and admissions to hospital related to carbon monoxide were divided by the size of the corresponding Canadian population that year, obtained from the Canadian census data. Ageand sex-standardized rates were obtained through direct standardization to the 1991 Canadian population, the standard reference population recommended by Health Canada for disease surveillance. ${ }^{15}$ Carbon monoxide poisoning death and admission to hospital rates were calculated nationally, by province, sex, age group $(\leq 14,15-24,25-34,35-44,45-54$, $55-64,65-74$ and $\geq 75$ yr) and site where carbon monoxide poisoning occurred.

Temporal trends in the age- and sex-standardized rates of death and admission to hospital for the corresponding time periods were expressed as the annual average percent change (AAPC) with 95\% confidence interval (CI). In this type of analysis, a Poisson regression model was conducted using the standardized rates as the dependent variable and the year of death or admission to hospital as the independent variable. The AAPC was calculated from the $\beta$ of the regression slope of $\log$ rates on year $(\mathrm{AAPC}=[\mathrm{e} \beta-1] 100)$. This approach estimates the magnitude of the increase or the decrease in rates observed over time. A Poisson regression model was also conducted to evaluate the determinants of carbon monoxide poisoning and adjusted for the following variables: age group, sex, month of occurrence and year of occurrence. Incidence rate ratios (IRRs) were obtained for these models. The analyses were conducted using SAS version 9.3.

\section{Results}

Between 1981 and 2009, there were 1808 deaths owing to unintentional nonfire-related carbon monoxide poisoning in Canada (Table 1). Between 1995 and 2010 there were 1984 admissions to hospital. We observed a $3.46 \%$ (95\% CI $-4.59 \%$ to $-2.31 \%$ ) average annual decrease in age- and sexstandardized death rates overall for Canada during the study period (1981-2009). A steady reduction in annual rates of hospital admission was also observed for the time period 19952010 (AAPC $-5.83 \%$, 95\% CI $-7.79 \%$ to $-3.83 \%$ ). Rates for unintentional nonfire-related carbon monoxide poisoning mortality and admission to hospital decreased over time in males and females (Figure 1 and Figure 2). Rates were consistently higher for males than for females.

Analyses by province are shown in Table 1 . The greatest reductions in mortality and admissions to hospital were seen in Saskatchewan (AAPC -29.48\%, 95\% CI -37.38\% to $-20.61 \%$ ) and New Brunswick (AAPC -23.76\%, 95\% CI $-39.19 \%$ to $-4.44 \%$ ), respectively. Average annual mortality rates were highest in the 3 prairie provinces (Alberta, Saskatchewan and Manitoba). In addition, a greater variation in average annual rates of admission to hospital by province was observed compared with mortality by province.

As shown in Figure 1 and Figure 2, accidental nonfirerelated carbon monoxide poisoning mortality and admission to hospital rates decreased significantly over time in both males and females, but the magnitude of these decreases differed 
across age groups (Table 2). Men aged 25-44 years had the highest average annual rates of admission to hospital and mortality owing to carbon monoxide poisoning.

The most common site of occurrence of unintentional nonfire-related carbon monoxide poisoning was at home. The average annual rates of mortality and admission to hospital for carbon monoxide exposure at home were 1.17 and 1.82 per million population, respectively (Table 3 ). These rates were more than double the rates observed for the other sites. When other or unknown sites of occurrence were excluded, carbon monoxide poisoning at home represented the lowest AAPC observed for mortality (AAPC $-5.09 \%, 95 \%$ CI -6.46 to -3.68 ) and admission to hospital (AAPC $-2.51 \%, 95 \%$ CI -5.31 to 0.34 ).

The investigation of the determinants of carbon monoxide poisoning showed that males had significantly elevated rates of mortality (IRR 5.31, 95\% CI 4.57 to 6.17 ) and hospital admission (IRR 2.77, 95\% CI 2.51 to 3.03) compared with females (Table 4). Statistically significant increased rates of admission to hospital (from September to March) and mortality (from October to April) for carbon monoxide poisoning were observed when compared with rates in August (Figure 3).

\section{Interpretation}

\section{Main findings}

We determined that mortality and admission to hospital rates for unintentional nonfire-related carbon monoxide poisoning decreased steadily in Canada over the past decades. Several provinces showed steady linear reductions in carbon monoxide poisoning death and admission to hospital rates. Although rates declined among both males and females, rates in males remained higher. Rates for all sites of occurrence of carbon monoxide poisoning decreased over time, but the magnitude of the decrease for this type of poisoning that occurred in home and residential environments was the lowest, excluding other/unknown sites. In addition, carbon monoxide poisoning mostly occurred from September to April, with peaks during the winter period.

\section{Comparison with other studies}

Decreasing mortality and admission to hospital rates reflect the trends observed in other developed countries. ${ }^{1,9,10}$ This decrease could be related to several factors. For instance, there may be improvements in the design, use and maintenance of home products and vehicles susceptible to the

\section{Table 1: Trends in age- and sex-standardized mortality and admission to hospital rates for unintentional nonfire-related carbon monoxide poisoning, by province and in Canada}

\begin{tabular}{|c|c|c|c|c|c|c|c|c|c|c|}
\hline \multirow[b]{3}{*}{ Location† } & \multicolumn{5}{|c|}{ Mortality } & \multicolumn{5}{|c|}{ Admission to hospital } \\
\hline & \multicolumn{2}{|c|}{ Rate $^{*}$} & \multicolumn{3}{|c|}{ Total study period, 1981-2009 } & \multicolumn{2}{|c|}{ Rate* $^{*}$} & \multicolumn{3}{|c|}{ Total study period, 1995-2010 } \\
\hline & 1981 & 2009 & $\begin{array}{l}\text { No. of } \\
\text { events }\end{array}$ & $\begin{array}{c}\text { Average } \\
\text { annual } \\
\text { rate* }^{*}\end{array}$ & AAPC $(95 \% \mathrm{Cl})$ & 1995 & 2010 & $\begin{array}{l}\text { No. of } \\
\text { events }\end{array}$ & $\begin{array}{c}\text { Average } \\
\text { annual } \\
\text { rate* }^{*}\end{array}$ & $\operatorname{AAPC}(95 \% \mathrm{Cl})$ \\
\hline Canada & 3.58 & 1.24 & 1808 & 2.18 & $\begin{array}{c}-3.46 \\
(-4.59 \text { to }-2.31)\end{array}$ & 7.07 & 2.57 & 1984 & 3.85 & $\begin{array}{c}-5.83 \\
(-7.79 \text { to }-3.83)\end{array}$ \\
\hline Alberta & 6.77 & 1.48 & 254 & 3.37 & $\begin{array}{c}-10.23 \\
(-18.01 \text { to }-1.73)\end{array}$ & 14.53 & 4.23 & 328 & 6.68 & $\begin{array}{c}-8.86 \\
(-11.42 \text { to }-6.27)\end{array}$ \\
\hline $\begin{array}{l}\text { British } \\
\text { Columbia }\end{array}$ & 2.07 & 0.00 & 195 & 1.99 & $\begin{array}{c}-6.04 \\
(-11.93 \text { to }-0.20)\end{array}$ & 7.25 & 4.72 & 365 & 5.39 & $\begin{array}{c}0.16 \\
(-5.37 \text { to } 6.14)\end{array}$ \\
\hline Manitoba & 8.14 & 0.00 & 112 & 3.48 & $\begin{array}{c}-15.14 \\
(-26.57 \text { to }-1.92)\end{array}$ & 9.19 & 0.63 & 70 & 3.82 & $\begin{array}{c}-11.13 \\
(-30.91 \text { to } 14.26)\end{array}$ \\
\hline New Brunswick & 3.90 & 6.32 & 72 & 3.27 & $\begin{array}{c}-12.19 \\
(-26.21 \text { to } 4.52)\end{array}$ & 9.07 & 2.21 & 76 & 6.00 & $\begin{array}{c}-23.76 \\
(-39.19 \text { to }-4.44)\end{array}$ \\
\hline $\begin{array}{l}\text { Newfoundland } \\
\text { and Labrador }\end{array}$ & 4.63 & 0.00 & 34 & 2.11 & $\begin{array}{c}-9.97 \\
(-25.58 \text { to } 8.94)\end{array}$ & 16.14 & 6.49 & 55 & 6.33 & $\begin{array}{c}1.08 \\
(-7.21 \text { to } 10.12)\end{array}$ \\
\hline Nova Scotia & 0.00 & 10.41 & 56 & 2.12 & $\begin{array}{c}-10.32 \\
(-25.11 \text { to } 7.3)\end{array}$ & 5.18 & 1.63 & 25 & 1.55 & $\begin{array}{c}-27.58 \\
(-18.00 \text { to } 98.52)\end{array}$ \\
\hline Ontario & 3.12 & 0.37 & 519 & 1.71 & $\begin{array}{c}-5.44 \\
(-7.31 \text { to }-3.54)\end{array}$ & 4.47 & 1.82 & 500 & 2.51 & $\begin{array}{c}-5.72 \\
(-8.42 \text { to }-3.04)\end{array}$ \\
\hline Quebec & 2.87 & 2.30 & 407 & 1.93 & $\begin{array}{c}-5.51 \\
(-11.30 \text { to } 0.71)\end{array}$ & 6.96 & 1.32 & 392 & 3.22 & $\begin{array}{c}-8.68 \\
(-13.28 \text { to }-3.91)\end{array}$ \\
\hline Saskatchewan & 7.54 & 0.00 & 128 & 4.47 & $\begin{array}{c}-29.48 \\
(-37.38 \text { to }-20.61)\end{array}$ & 5.76 & 7.98 & 145 & 8.89 & $\begin{array}{c}-3.90 \\
(-9.36 \text { to } 1.91)\end{array}$ \\
\hline
\end{tabular}


release of carbon monoxide. In particular, the introduction of catalytic converters in vehicles resulted in decreased carbon monoxide emissions. ${ }^{16}$ Increased awareness of the adverse health effects of accidental carbon monoxide poisoning through prevention programs or media coverage of fatal cases of carbon monoxide poisoning may also explain these findings. In addition, medical care for patients with carbon monoxide poisoning likely improved over time. The use of carbon monoxide alarms in homes may have reduced the number of cases of carbon monoxide poisoning. However, a recent home safety survey conducted across Canada showed that $60 \%$ of Canadians do not have a carbon monoxide alarm in their homes. ${ }^{17}$ Male patients in Canada had the highest rates of carbon monoxide mortality and admission to hospital, which is consistent with previous studies. ${ }^{1,9,10}$ Behavioural factors could explain these findings: men may have more opportunities to use combustion appliances inappropriately or without appropriate ventilation. ${ }^{18}$ The fact that these rates were highest for carbon monoxide poisoning that occurred in home and residential environments is consistent with previous reports from the UK and the US, although the magnitude of the trends was not reported in

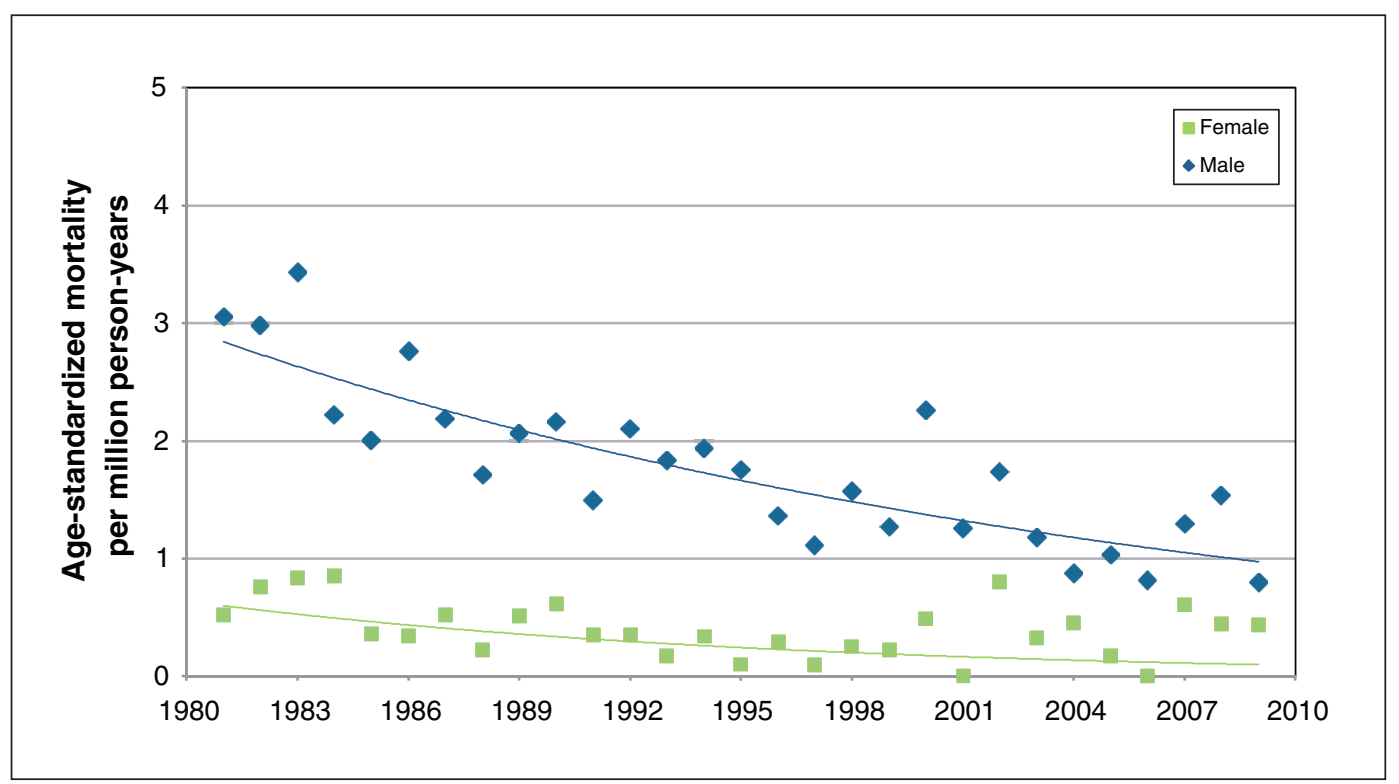

Figure 1: Age-standardized mortality trends for unintentional nonfire-related carbon monoxide poisoning in Canada, by sex. The average annual percent change was $-3.75(95 \% \mathrm{Cl}-4.68$ to -2.82$)$ for males and -6.21 $(95 \% \mathrm{Cl}-12.57$ to 0.73$)$ for females.

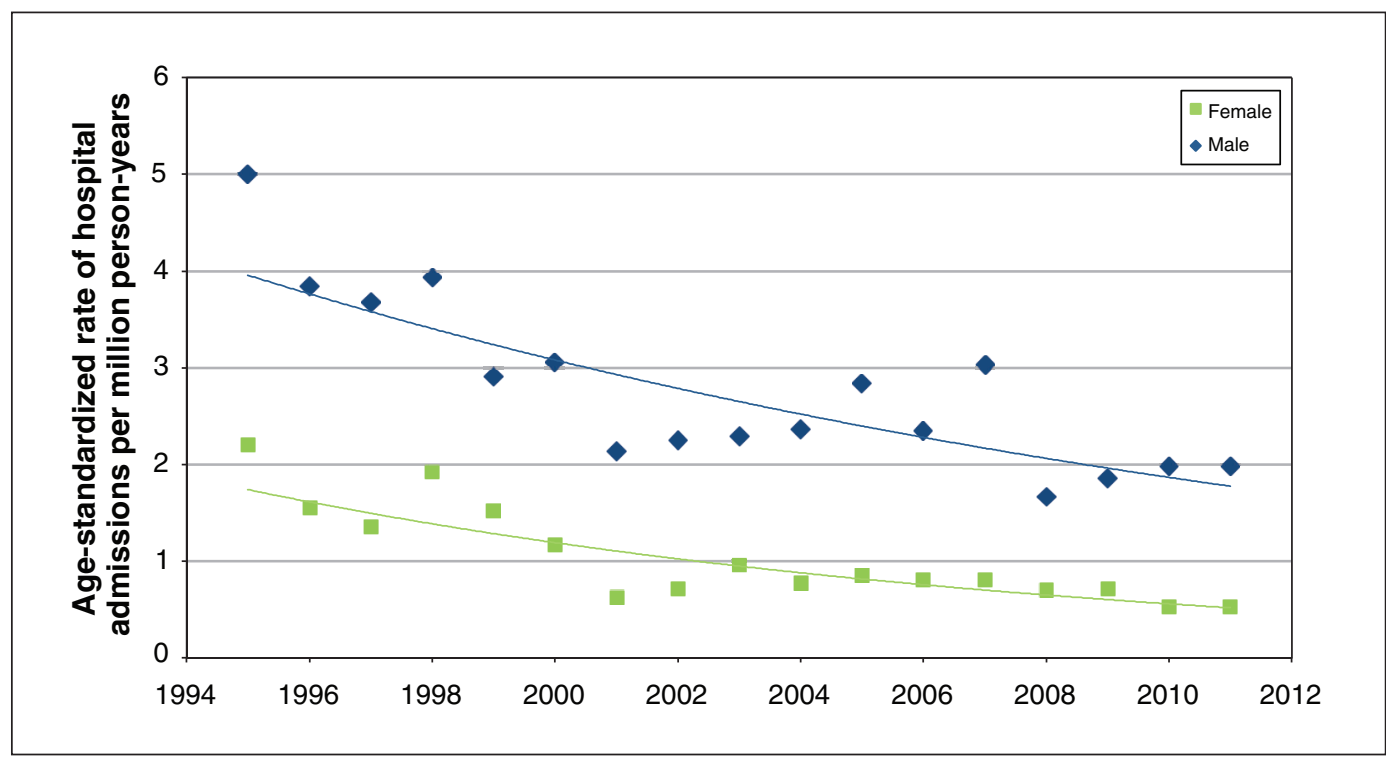

Figure 2: Age-standardized rates for admission to hospital for unintentional nonfire-related carbon monoxide poisoning in Canada, by sex. The average annual percent change was $-4.89(95 \% \mathrm{Cl}-6.62$ to -3.13$)$ for males and $-7.29(95 \% \mathrm{Cl}-9.40$ to -5.12$)$ for females. 
these studies. ${ }^{8,9}$ Our results suggest that continued efforts should focus on educating Canadians on how to prevent carbon monoxide poisoning in home and residential environments. Finally, carbon monoxide poisoning seems to occur mostly during the cooler months in Canada, which is similar to what has been reported in the US. ${ }^{19}$ Vehicle exhaust systems or home-heating vents may become obstructed with snow, causing accumulation of carbon monoxide in homes or inside the passenger compartment of a vehicle. ${ }^{20}$

\section{Strengths and limitations}

Strengths of our study include the use of national health administrative databases allowing analyses by province, age group, sex and site of occurrence of carbon monoxide poisoning. The temporal resolution of the data also allowed us to describe the monthly distribution of carbon monoxide poisoning.

Our study has several limitations. First, we could not assess specific mechanisms or consumer products through which unintentional nonfire-related carbon monoxide poisoning

\begin{tabular}{|c|c|c|c|c|c|c|c|c|c|c|}
\hline \multirow[b]{3}{*}{ Age, yr } & \multicolumn{5}{|c|}{ Mortality } & \multicolumn{5}{|c|}{ Admission to hospital } \\
\hline & \multicolumn{2}{|c|}{ Rate $^{*}$} & \multicolumn{3}{|c|}{ Overall study period, 1981-1999 } & \multicolumn{2}{|c|}{ Rate* $^{*}$} & \multicolumn{3}{|c|}{ Overall study period, 1995-2010 } \\
\hline & 1981 & 1999 & $\begin{array}{l}\text { No. of } \\
\text { events }\end{array}$ & $\begin{array}{c}\text { Average } \\
\text { annual } \\
\text { rate* }^{*}\end{array}$ & AAPC $(95 \% \mathrm{Cl})$ & 1995 & 2010 & $\begin{array}{l}\text { No. of } \\
\text { events }\end{array}$ & $\begin{array}{c}\text { Average } \\
\text { annual } \\
\text { rate }^{*}\end{array}$ & AAPC $(95 \% \mathrm{Cl})$ \\
\hline \multicolumn{11}{|l|}{ Female } \\
\hline$\leq 14$ & 0.04 & 0.03 & 9 & 0.02 & $\begin{array}{c}-8.13 \\
(-22.20 \text { to } 8.47)\end{array}$ & 0.38 & 0.11 & 77 & 0.17 & $\begin{array}{c}-11.26 \\
(-26.01 \text { to } 6.52)\end{array}$ \\
\hline $15-24$ & 0.18 & 0.03 & 47 & 0.08 & $\begin{array}{c}-22.63 \\
(-32.64 \text { to }-11.21)\end{array}$ & 0.29 & 0.09 & 69 & 0.15 & $\begin{array}{c}-20.21 \\
(-30.79 \text { to }-8.01)\end{array}$ \\
\hline $25-34$ & 0.04 & 0.01 & 21 & 0.04 & $\begin{array}{c}-24.48 \\
(-33.11 \text { to }-14.82)\end{array}$ & 0.41 & 0.08 & 73 & 0.18 & $\begin{array}{c}-8.68 \\
(-14.01 \text { to }-3.02)\end{array}$ \\
\hline $35-44$ & 0.05 & 0.12 & 31 & 0.06 & $\begin{array}{c}-12.17 \\
(-23.20 \text { to } 0.53)\end{array}$ & 0.36 & 0.03 & 86 & 0.17 & $\begin{array}{c}-8.51 \\
(-13.69 \text { to }-3.12)\end{array}$ \\
\hline $45-54$ & 0.04 & 0.03 & 26 & 0.05 & $\begin{array}{c}-7.25 \\
(-21.66 \text { to } 9.78)\end{array}$ & 0.26 & 0.08 & 73 & 0.11 & $\begin{array}{c}-8.29 \\
(-20.17 \text { to } 5.11)\end{array}$ \\
\hline $55-64$ & 0.04 & 0.01 & 23 & 0.04 & $\begin{array}{c}-5.57 \\
(-19.91 \text { to } 11.16)\end{array}$ & 0.17 & 0.08 & 53 & 0.09 & $\begin{array}{c}-5.73 \\
(-11.01 \text { to }-0.09)\end{array}$ \\
\hline $65-74$ & 0.05 & 0.03 & 29 & 0.06 & $\begin{array}{c}5.30 \\
(-11.69 \text { to } 25.56)\end{array}$ & 0.17 & 0.11 & 44 & 0.09 & $\begin{array}{c}-9.61 \\
(-23.13 \text { to } 6.2)\end{array}$ \\
\hline$\geq 75$ & 0.10 & 0.01 & 23 & 0.05 & $\begin{array}{c}-18.23 \\
(-28.77 \text { to }-6.01)\end{array}$ & 0.16 & 0.06 & 68 & 0.11 & $\begin{array}{c}0.26 \\
(-5.92 \text { to } 6.80)\end{array}$ \\
\hline \multicolumn{11}{|l|}{ Male } \\
\hline$\leq 14$ & 0.07 & 0.03 & 23 & 0.04 & $\begin{array}{c}-10.32 \\
(-25.61 \text { to } 8.13)\end{array}$ & 0.62 & 0.26 & 133 & 0.29 & $\begin{array}{c}-5.31 \\
(-9.18 \text { to }-1.30)\end{array}$ \\
\hline $15-24$ & 0.62 & 0.03 & 157 & 0.27 & $\begin{array}{c}-12.72 \\
(-16.11 \text { to }-9.22)\end{array}$ & 0.89 & 0.09 & 150 & 0.32 & $\begin{array}{c}-9.44 \\
(-15.39 \text { to }-3.00)\end{array}$ \\
\hline $25-34$ & 0.71 & 0.16 & 198 & 0.40 & $\begin{array}{c}-9.31 \\
(-12.48--6.01)\end{array}$ & 0.60 & 0.69 & 204 & 0.51 & $\begin{array}{c}-2.52 \\
(-6.37 \text { to } 1.59)\end{array}$ \\
\hline $35-44$ & 0.46 & 0.42 & 205 & 0.41 & $\begin{array}{c}-0.88 \\
(-5.02 \text { to } 3.40)\end{array}$ & 0.85 & 0.27 & 265 & 0.52 & $\begin{array}{c}-6.66 \\
(-9.11 \text { to }-4.23)\end{array}$ \\
\hline $45-54$ & 0.43 & 0.31 & 173 & 0.32 & $\begin{array}{c}-1.80 \\
(-3.91 \text { to } 0.37)\end{array}$ & 0.92 & 0.28 & 257 & 0.39 & $\begin{array}{c}-4.83 \\
(-7.48 \text { to }-2.09)\end{array}$ \\
\hline $55-64$ & 0.29 & 0.09 & 137 & 0.26 & $\begin{array}{c}-4.88 \\
(-8.11 \text { to }-1.49)\end{array}$ & 0.55 & 0.18 & 221 & 0.38 & $\begin{array}{c}-5.74 \\
(-8.87 \text { to }-2.40)\end{array}$ \\
\hline $65-74$ & 0.23 & 0.09 & 91 & 0.18 & $\begin{array}{c}-2.64 \\
(-7.27 \text { to } 2.19)\end{array}$ & 0.16 & 0.20 & 130 & 0.24 & $\begin{array}{c}-2.09 \\
(-7.20 \text { to } 3.41)\end{array}$ \\
\hline$\geq 75$ & 0.15 & 0.17 & 70 & 0.14 & $\begin{array}{c}-1.36 \\
(-12.01 \text { to } 10.63)\end{array}$ & 0.32 & 0.08 & 81 & 0.13 & $\begin{array}{c}-2.89 \\
(-7.79 \text { to } 2.32)\end{array}$ \\
\hline
\end{tabular}




\section{OPEN}

Research

occurred because of a lack of availability of information in the administrative data used. Second, the change from ICD-9 to ICD-10 in the administrative databases may have affected the trends observed. A study in Europe showed that the move from ICD-9 to ICD-10 resulted in an increase in reported cases of carbon monoxide poisoning in some European countries, whereas, in others, the ICD-10 implementation decreased the identification of carbon monoxide cases in health administrative databases. ${ }^{10}$ In Canada, no studies have investigated the impact of the change from ICD-9 to ICD-10 on the identification of cases of carbon monoxide poisoning and, therefore, we cannot speculate on the extent to which this may affect our estimates. Third, the small number of events reported for some provinces and territories affected the statistical power to detect trends in rates over time for these jurisdictions. The large variation observed in average annual rates of admission to hospital by province compared with mortality suggests a lack of consistency across provinces in the coding for carbon monoxide poisoning. Finally, we relied only on admission to hospital rates to assess trends in nonfatal

\begin{tabular}{|c|c|c|c|c|c|c|c|c|c|c|}
\hline \multirow[b]{3}{*}{ Exposure site } & \multicolumn{5}{|c|}{ Mortality } & \multicolumn{5}{|c|}{ Admission to hospital } \\
\hline & \multicolumn{2}{|c|}{ Rate* $^{*}$} & \multicolumn{3}{|c|}{ Total study period, 1981-2009 } & \multicolumn{2}{|c|}{ Rate* $^{*}$} & \multicolumn{3}{|c|}{ Total study period, 1995-2010 } \\
\hline & 1981 & 2009 & $\begin{array}{l}\text { No. of } \\
\text { events }\end{array}$ & $\begin{array}{c}\text { Average } \\
\text { annual } \\
\text { rate }^{*}\end{array}$ & $\operatorname{AAPC}(95 \% \mathrm{Cl})$ & 1995 & 2010 & $\begin{array}{l}\text { No. of } \\
\text { events }\end{array}$ & $\begin{array}{c}\text { Average } \\
\text { annual } \\
\text { rate* }^{*}\end{array}$ & $\operatorname{AAPC}(95 \% \mathrm{Cl})$ \\
\hline Home/residential & 1.94 & 0.66 & 930 & 1.17 & $\begin{array}{c}-5.09 \\
(-6.46 \text { to }-3.68)\end{array}$ & 2.65 & 1.59 & 942 & 1.82 & $\begin{array}{c}-2.51 \\
(-5.32 \text { to } 0.34)\end{array}$ \\
\hline Occupational & 0.27 & 0.08 & 117 & 0.15 & $\begin{array}{c}-6.48 \\
(-10.37 \text { to }-2.39)\end{array}$ & 1.22 & 0.17 & 264 & 0.52 & $\begin{array}{c}-6.41 \\
(-10.73 \text { to }-1.92)\end{array}$ \\
\hline $\begin{array}{l}\text { Recreation/sports } \\
\text { facility }\end{array}$ & 0.03 & 0.00 & 23 & 0.03 & $\begin{array}{c}-13.07 \\
(-19.38 \text { to }-6.29)\end{array}$ & 0.10 & 0.03 & 19 & 0.04 & $\begin{array}{c}-23.05 \\
(-35.51 \text { to }-8.23)\end{array}$ \\
\hline Public area & 0.50 & 0.06 & 105 & 0.13 & $\begin{array}{c}-10.10 \\
(-17.01 \text { to }-2.60)\end{array}$ & 0.17 & 0.08 & 54 & 0.11 & $\begin{array}{c}-12.97 \\
(-23.88 \text { to }-0.48)\end{array}$ \\
\hline Other/unknown & 0.36 & 0.14 & 633 & 0.21 & $\begin{array}{c}-3.80 \\
(-8.48 \text { to } 1.23)\end{array}$ & 1.33 & 0.66 & 705 & 0.82 & $\begin{array}{c}-2.52 \\
(-6.01 \text { to } 1.10)\end{array}$ \\
\hline
\end{tabular}

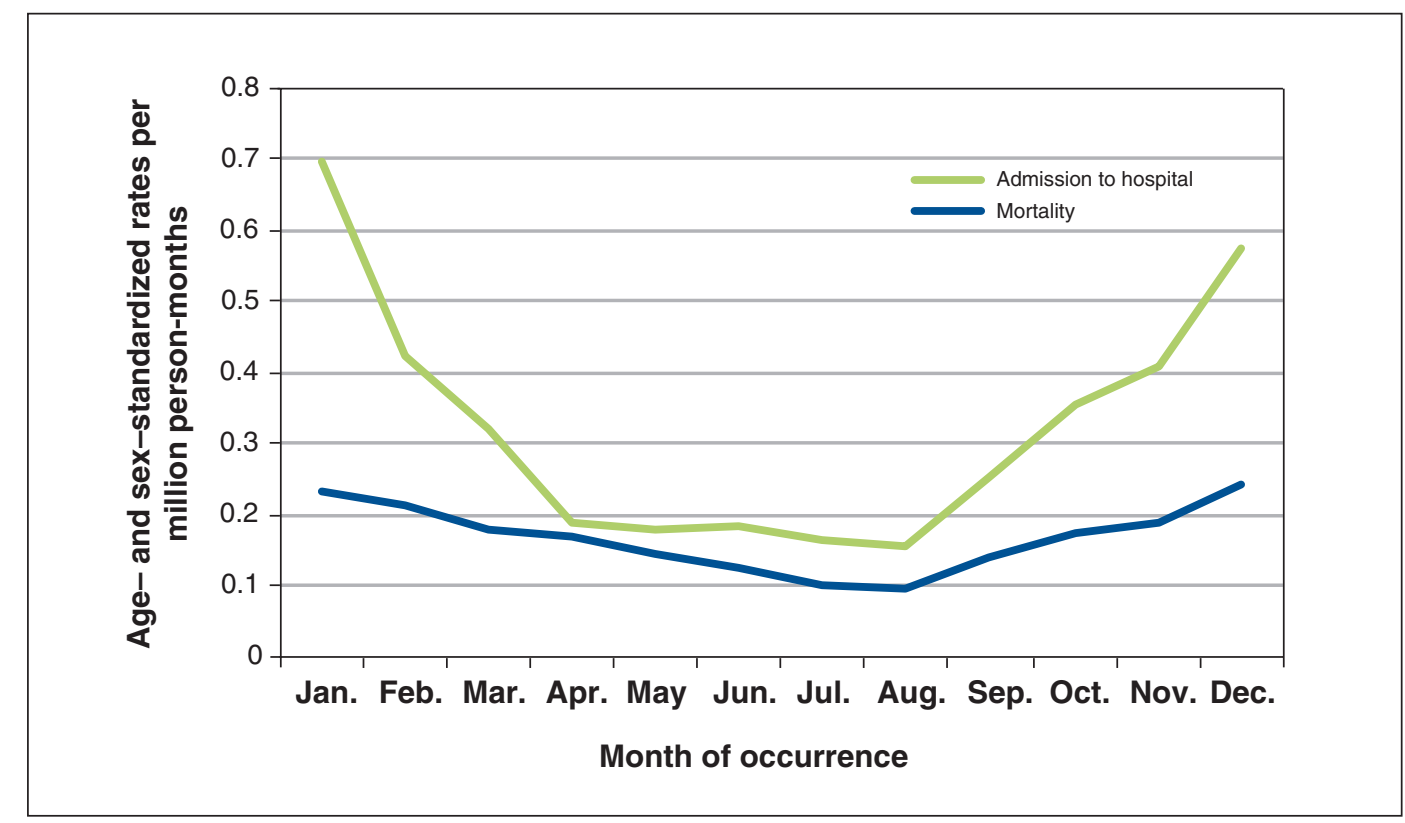

Figure 3: Average mortality (1981-2009) and admission to hospital (1995-2010) rates for unintentional nonfirerelated carbon monoxide poisoning in Canada, by month. 
carbon monoxide poisoning, which is not optimal given that people who are admitted to hospital for carbon monoxide poisoning usually have the most severe poisoning. For example,

Table 4: Selected determinants of mortality (1981-1999) and admissions to hospital (1995-2010) for unintentional nonfire-related carbon monoxide poisoning in Canada

\begin{tabular}{lcc}
\hline $\begin{array}{l}\text { Selected } \\
\text { determinants }\end{array}$ & Mortality, & $\begin{array}{c}\text { Admission to } \\
\text { hospital, } \\
\text { IRR* }(95 \% \mathrm{Cl})\end{array}$ \\
\hline IRR* $(95 \% \mathrm{Cl})$
\end{tabular}

Sex and age, yr

Female

\begin{tabular}{|lcc|}
\hline$\leq 14$ & $0.36(0.17-0.79)$ & $0.83(0.60-1.14)$ \\
\hline $15-24$ & $2.46(1.48-4.14)$ & $1.02(0.73-1.42)$ \\
\hline $25-34$ & 1.00 & 1.00 \\
\hline $35-44$ & $1.75(1.07-3.06)$ & $1.04(0.76-1.42)$ \\
\hline $45-54$ & $1.93(1.08-3.49)$ & $1.00(0.73-1.39)$ \\
\hline $55-64$ & $2.10(1.16-3.78)$ & $1.04(0.73-1.49)$ \\
\hline $65-74$ & $3.35(1.92-5.87)$ & $1.15(0.79-1.68)$ \\
\hline$\geq 75$ & $3.56(1.97-6.42)$ & $1.90(1.36-2.64)$ \\
\hline Male & & \\
\hline$\leq 14$ & $\mathbf{0 . 1 0 ( 0 . 0 6 - 0 . 1 5 )}$ & $\mathbf{0 . 5 0 ( 0 . 4 0 - 0 . 6 2 )}$ \\
\hline $15-24$ & $0.86(0.70-1.06)$ & $\mathbf{0 . 7 6}(\mathbf{0 . 6 2 - 0 . 9 4 )}$ \\
\hline $25-34$ & 1.00 & 1.00 \\
\hline $35-44$ & $1.19(0.98-1.45)$ & $1.16(0.97-1.38)$ \\
\hline $45-54$ & $\mathbf{1 . 3 8 ( 1 . 1 2 - 1 . 6 8 )}$ & $\mathbf{1 . 2 7}(\mathbf{1 . 0 6 - 1 . 5 4 )}$ \\
\hline $55-64$ & $\mathbf{1 . 4 2 ( 1 . 1 3 - 1 . 7 5 )}$ & $\mathbf{1 . 6 0 ( 1 . 3 2 - 1 . 9 3 )}$ \\
\hline $65-74$ & $\mathbf{1 . 3 5 ( 1 . 0 5 - 1 . 7 3 )}$ & $\mathbf{1 . 3 9}(\mathbf{1 . 1 2 - 1 . 7 3 )}$ \\
\hline$\geq 75$ & $\mathbf{1 . 8 8 ( 1 . 4 3 - 2 . 4 8 )}$ & $\mathbf{1 . 3 2}(\mathbf{1 . 0 0 - 1 . 6 8 )}$ \\
\hline Sex & &
\end{tabular}

\section{Sex}

Female

1.00

1.00

Male

$5.31(4.57-6.17)$

$2.77(2.51-3.03)$

Month of occurrence

\begin{tabular}{|c|c|c|}
\hline January & $2.23(1.67-2.97)$ & $4.48(3.56-5.70)$ \\
\hline February & $2.14(1.60-2.86)$ & $2.71(2.10-3.52)$ \\
\hline March & $1.49(1.08-2.03)$ & $2.08(1.58-2.72)$ \\
\hline April & $1.51(1.09-2.05)$ & $1.22(0.90-1.63)$ \\
\hline May & $1.38(1.00-1.90)$ & $1.17(0.87-1.58)$ \\
\hline June & $1.22(0.89-1.70)$ & $1.19(0.88-1.60)$ \\
\hline July & $1.07(0.77-1.51)$ & $1.06(0.78-1.44)$ \\
\hline August & 1.00 & 1.00 \\
\hline September & $1.35(0.98-1.86)$ & $1.60(1.21-2.14)$ \\
\hline October & 1.75 (1.30-2.39) & $2.27(1.75-2.97)$ \\
\hline November & $1.67(1.23-2.27)$ & $2.59(2.01-3.39)$ \\
\hline December & $2.18(1.65-2.94)$ & $3.71(1.89-4.76)$ \\
\hline
\end{tabular}

Note: $\mathrm{Cl}$ = confidence interval, IRR = incident rate ratio. Statistically significant results are shown in boldface.

*Mutually adjusted for age group, sex, and month and year of occurrence. in the US, only $10 \%$ of cases of unintentional nonfire-related carbon monoxide poisoning are admitted to hospital. ${ }^{2}$ The use of poison control centre calls or emergency department data for nonfatal cases of carbon monoxide poisoning should be considered in public health surveillance systems. ${ }^{21,22}$ However, these data were not available across Canada.

\section{Conclusion}

Mortality and admission to hospital rates for unintentional nonfire-related carbon monoxide poisoning have decreased over time in Canada. However, continued efforts should focus on reducing the occurrence of carbon monoxide poisoning, particularly among males and during the cooler months, and implementing appropriate measures to prevent carbon monoxide poisoning at home, such as supporting the design of heating and cooking products to improve combustion safety and encouraging the use of home carbon monoxide detectors. Public health surveillance of carbon monoxide poisoning should consider broader and novel sources of data, such as information from poison control centre call records.

\section{References}

1. Centers for Disease Control and Prevention (CDC). Carbon monoxide exposures-United States, 2000-2009. MMWR Morb Mortal Wkly Rep 2011;60:1014-7.

2. Centers for Disease Control and Prevention (CDC). Unintentional poisoning deaths-United States, 1999-2004. MMWR Morb Mortal Wkly Rep 2007; 56:93-6.

3. Clifton JC II, Leikin JB, Hryhorczuk DO, et al. Surveillance for carbon monoxide poisoning using a national media clipping service. Am 7 Emerg Med 2001;19:106-8.

4. Rapport des maladies et intoxications d'origine chimique declarées au Québec de 2005 à 2011. Montréal: Ministère de la Santé et des Services sociaux; 2011.

5. Wright J. Chronic and occult carbon monoxide poisoning: we don't know what we're missing. Emerg Med f 2002;19:386-90.

6. Iqbal S, Clower JH, Boehmer TK, et al. Carbon monoxide-related hospitalizations in the U.S.: evaluation of a web-based query system for public health surveillance. Public Health Rep 2010;125:423-32.

7. Centers for Disease Control and Prevention (CDC). Nonfatal, unintentional, non-fire-related carbon monoxide exposures-United States, 2004-2006. MMWR Morb Mortal Wkly Rep 2008;57:896-9.

8. Mott JA, Wolfe MI, Alverson CJ, et al. National vehicle emissions policies and practices and declining US carbon monoxide-related mortality. 7AMA 2002; 288:988-95

9. Fisher DS, Leonardi G, Flanagan RJ. Fatal unintentional non-fire-related carbon monoxide poisoning: England and Wales, 1979-2012. Clin Toxicol (Phila) 2014;52:166-70.

10. Braubach M, Algoet A, Beaton M, et al. Mortality associated with exposure to carbon monoxide in WHO European Member States. Indoor Air 2013; 23:115-25.

11. Iqbal S, Law HZ, Clower JH, et al. Hospital burden of unintentional carbon monoxide poisoning in the United States, 2007. Am 7 Emerg Med 2012; 30:657-64.

12. Vital Statistics - Death Database, detailed information for 2011. In: Statistics Canada [website]. Available: www23.statcan.gc.ca/imdb/p2SV.pl? Function=get Survey\&SDDS=3233 (accessed 2014 May 27).

13. Ball LB, Macdonald SC, Mott JA, et al. Carbon monoxide-related injury estimation using ICD-coded data: methodologic implications for public health surveillance. Arch Environ Occup Health 2005;60:119-27.

14. The Hospital Morbidity Database $(H M D B)$. Toronto: Canadian Institute for Health Information; 2014; Available: www.cihi.ca/cihi-ext-portal/internet/en/ document/types+of+care/hospital+care/acute+care/hmdb_metadata (accessed 2015 May 12)

15. Kennedy CC, Brien SE, Tu JV; Canadian Cardiovascular Outcomes Research Team. An overview of the methods and data used in the CCORT Canadian Cardiovascular Atlas project. Can 7 Cardiol 2003;19:655-63.

16. Shelef $M$. Unanticipated benefits of automotive emission control: reduction in fatalities by motor vehicle exhaust gas. Sci Total Environ 1994;146-147:93-101.

17. Carbon monoxide education is key. In: Hawkins-Gignac Foundation for CO Educa tion [website]. Available: www.endthesilence.ca/stay-safe/ (accessed 2015 May12).

18. Fisher DS, Bowskill S, Saliba L, et al. Unintentional domestic non-fire related carbon monoxide poisoning: data from media reports, UK/Republic of Ireland 
1986-2011. Clin Toxicol (Phila) 2013;51:409-16.

19. Harduar-Morano L, Watkins S. Review of unintentional non-fire-related carbon monoxide poisoning morbidity and mortality in Florida, 1999-2007. Public Health Rep 2011;126:240-50.

20. Johnson-Arbor KK, Quental AS, Li D. A comparison of carbon monoxide exposures after snowstorms and power outages. Am 7 Prev Med 2014;46:481-6.

21. Durigon M, Elliott C, Purssell R, et al. Canadian poison control centres: preliminary assessment of their potential as a resource for public health surveillance. Clin Toxicol (Pbila) 2013;51:886-91.

22. Hampson NB. Trends in the incidence of carbon monoxide poisoning in the United States. Am f Emerg Med 2005;23:838-41.

Affiliations: Air Health Science Division (Lavigne, Weichenthal, Wong, Dugandzic), Health Canada, Ottawa, Ont.; Population Studies Division (Smith-Doiron), Health Canada, Ottawa, Ont.; British Columbia Centre for Disease Control (Kosatsky), Vancouver, BC; Interdisciplinary School of Health Sciences (Lavigne), University of Ottawa, Ottawa, Ont.;
Department of Epidemiology, Biostatistics and Occupational Health (Weichenthal), McGill University, Montréal, Que.

Contributors: Eric Lavigne, Scott Weichenthal, Rose Dugandzic and Tom Kosatsky were responsible for the study concept and design and supervised the study. Eric Lavigne and Marc Smith-Doiron acquired the data and performed the statistical analysis under the supervision of Tom Kosatsky. Eric Lavigne drafted the manuscript. All of the authors analyzed and interpreted the data, critically revised it for intellectual content, approved the final version to be published and agreed to act as guarantors of the work.

Acknowledgements: The authors would like to thank Dave Stieb and Minh T. Do for their comments on an earlier version of the manuscript.

Supplemental information: For reviewer comments and the original submission of this manuscript, please see www.cmajopen.ca/content/3/2/ E223/suppl/DC1 